\title{
Structural equation modelling of perception for sustainable agriculture as climate change mitigation strategy in Ghana
}

\author{
Jacob Ankamah ${ }^{1,2^{*}}$, Theophilus Tweneboah Kodua ${ }^{2}$ and Mary Addae ${ }^{2}$
}

\begin{abstract}
Background: Ghana's agriculture sector has contributed significantly to the country's Gross Domestic Product (GDP) over the past decades even though there has been persistent decline of about $12.8 \%$ in the last 7 years. It decreased from 31.8\% in 2009 to merely 19\% as of September 2015, a period of 7 years. In spite of these trends, sustainable agriculture has been observed to be a game changer in agricultural development and growth globally. Sustainable agriculture is partly dependent on the attitude of the present agriculture students who represent the potential officers to impart sustainable agriculture knowledge to farmers. It is therefore relevant to assess the perception of students toward the concept of sustainable agriculture on climate change to inform policy decisions and interventions.

Methods: To assess the perception of students' toward sustainable agriculture, this study sampled 120 final year undergraduate students' in the School of Agriculture at the College of Basic and Applied Sciences, University of Ghana, Legon. The study used a well-structured questionnaire to solicit students' perception for sustainable agriculture, its' adoption barriers and perceived strategies to address the barriers in Ghana.
\end{abstract}

Results: Findings indicated that students' perception for sustainable agriculture is positive. Majority of the students (78.00\%) were of the view that sustainable agricultural practices would help protect the environment and our natural resources, therefore could mitigate adverse effects of climate change on agricultural activities.

Conclusions: Students ranked perceived barriers to sustainable agriculture adoption as; economic costs, lack of knowledge and land tenure constraints. Strategic ways to address the barriers were identified as farmer-to-farmer education, provision of financial incentives, developing training and partnership programs, and participatory learning.

Keywords: Perception, Student, Sustainable agriculture, Barriers, Strategies to address barriers

\section{Background}

Agriculture has been the backbone of Ghana's economy over the past decades, and it contributions to Gross Domestic Product (GDP) significantly increases Ghana's economic growth. The GDP of Ghana has declined by $12.8 \%$ in just 7 years. It decreased from $31.8 \%$ in 2009 to merely $19 \%$ as of September 2015, a period of 7 years. There is the need to examine variables that adversely

\footnotetext{
*Correspondence: jacob.ankamah@uni-jena.de

${ }^{1}$ Department of Economics, Friedrich-Schiller-Universität Jena, Jena, Germany

Full list of author information is available at the end of the article
}

affect sustainability of the agriculture sector. The major sub-sectors under the agriculture sector in Ghana are crops (including cocoa), livestock, fisheries, forestry and logging (MoFA 2016; Kwarase 2017; Agbenyo et al. 2019). Crops include cash crops (cocoa, oil palm, etc.), cereals, starchy staples and legumes, fruits and vegetables. Livestock includes cattle, sheep, goats, pigs and poultry. It is worth knowing that the crop sub-sector is the largest of all the sub-sectors (MoFA 2016; Kwarase 2017).

Paramati et al. (2017) reported on the trends in agricultural production efficiency in African countries. Their report showed that Ghana is one of the countries 
that were "never efficient" and labelled "struggler" in terms of agricultural production efficiency from 1995 to 2012. Production outputs from major sub-sectors under the agriculture sector are below optimum compared to expected attainable levels (MoFA 2016).

As indicated in Fig. 1, there is a declining rate of the agriculture sector to Ghana's Gross Domestic Product (GDP). It shows that sectoral growth in agriculture has not been consistent. That is from 0.8 percent in 2011, it increased to 5.2 percent in 2013, decreased to 4.6 percent in 2014 and contracted to 2.5 percent in 2015 (GSS 2016). A thorough analyses of the major sub-sectors reveal that except for livestock, growth rates have been declining in sub-sectors including fishing, cocoa, forestry and logging since 2012 and for crops since 2013 (GSS 2016). As the world human population increases, which had exceeded 7 billion and forecasted to grow above 9 billion will necessitate an increase in agricultural output of about 60 percent (Alexandratos and Bruinsma 2012) to meet the food demand from a growing human population. This demand will put more pressures on agriculture as well as natural resources needed to increase food production if the goal of no hunger of the United Nations (UN) sustainable development is to be met (Abraham and Pingali
2020). The onus lies on the agriculture sector to supply future food needs, hence sector players like extension officers, agriculture students', farmers etc. need to better understand the complex processes and interactions of key factors such as stable agricultural land and the dynamism of cultural practices relevant for the sector's development. In many developing countries, agriculture plays a vital role in the rural economy by addressing the issues of poverty alleviation, food security and acts as a source of stable income generation (Adeola and Adetunbi 2015). In response to these multiple challenges both in terms of food provision, socio-cultural and environmental benefits without depleting the natural resources, there is a need to shift to a more sustainable system of agriculture.

Sustainable agriculture is an integrated system of plant and animal production practices having a site-specific application that will, over the long term satisfy human food and fibre needs whiles enhancing the environmental quality and natural resources upon which the agriculture economy entirely depends (Williams 2000; Veisi et al. 2008; Adeola and Adetunbi 2015). It's the practices that make the most efficient use of non-renewable resources and on-farm resources and integrate, where appropriate natural biological cycles and controls; sustain

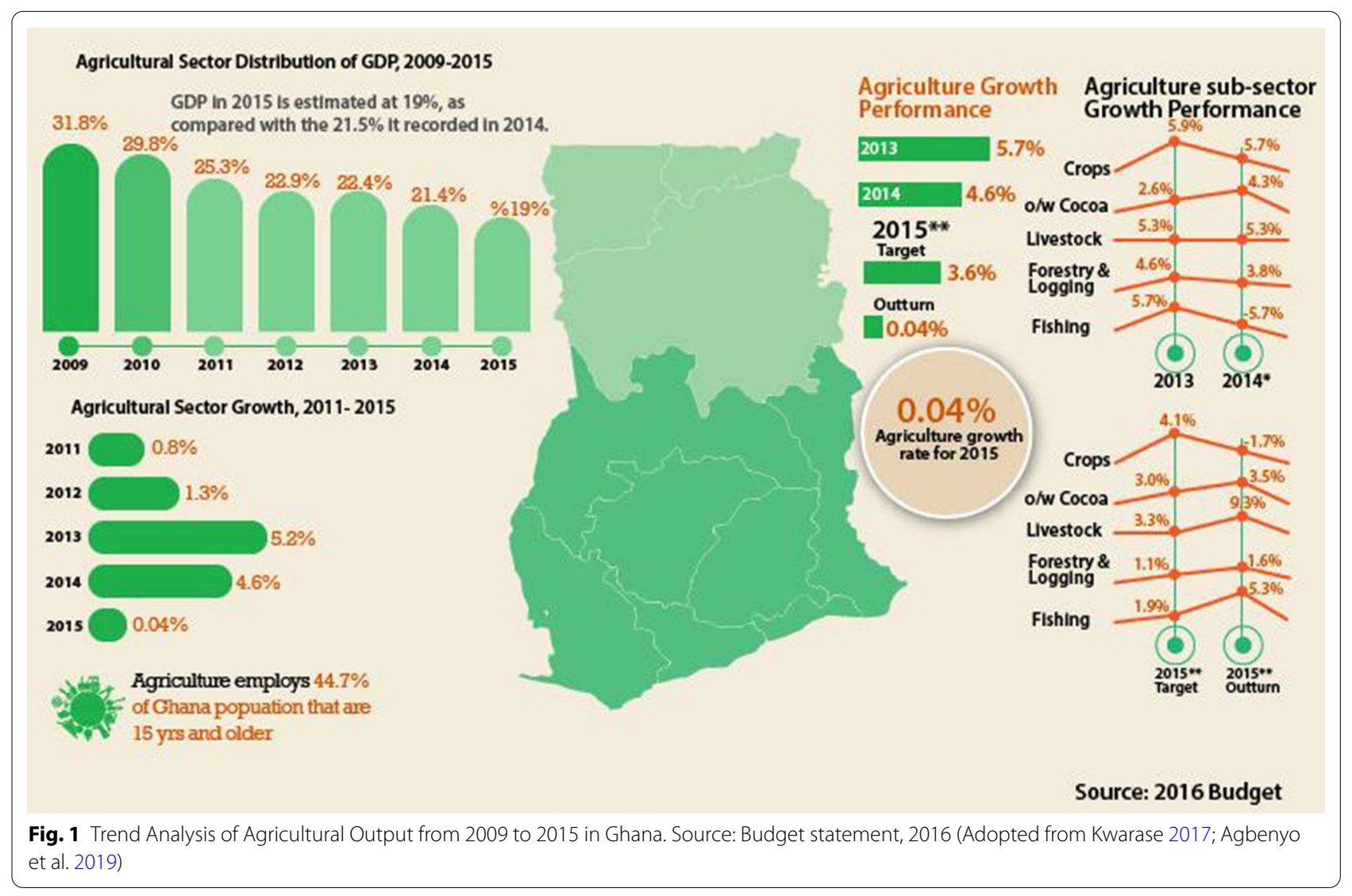


the economic viability of farm operations; and enhance finally the quality life of farmers and society in general.

Cultural practices such as indiscriminate and excessive application of chemical fertilizers has led to health and environmental hazards and have resulted in stakeholders desperately finding alternative practices capable of ensuring competitive yields whilst protecting soil health (Altieri 2002). Various interventions have been implemented with the aim of making the world a better place for living since all living organism feed on the products of the earth, animals and humans in particular depend largely on agricultural products to meet their consumption needs (Hoekstra and Chapagain, 2006). An example of such intervention is the advocacy for new approach to farming, usually referred to as sustainable agriculture (Altieri, 2002). This approach requires that agricultural practices are friendlier to the environment and also maintain lasting ecological balance of the soil ecosystem. Policies have been formulated over the years to ensure a world free of poverty and food security, one popular policy amongst sustainable agriculture policies is the Sustainable Development Solutions Network. According to FAO (2016) report in United Nations Sustainable Development Solutions Network, agriculture supply various life sustaining needs; agricultural activity is the world largest user and occupier of more than one third of the earth's terrestrial surface. Besides, agriculture is a source of employment to majority of people especially in sub-Saharan Africa (Schaffnit-Chatterjee 2014). The numerous benefits from agriculture have been projected to decline due to unsustainable cultural practices farmers' recently adopt. The United States Department of Agriculture in 2015 raised concerns that conventional agriculture referring to the farming systems which include the use of synthetic chemical fertilizers, pesticides, herbicides and other continual inputs, genetically modified organisms, concentrated animal feeding operations, heavy irrigation, intensive tillage, or concentrated monoculture production had taken over the traditional environmentally friendly organic system across the world. Conventional agriculture has replaced sustainable agriculture or organic farming in the twenty-first century (Tuomistoa et al. 2012). Concerns about the impact of conventional agriculture on humans and the entire environment have raised global awareness on how to sustain the earth from degradation and other negative potential impacts (Tuomistoa et al. 2012). According to Agbaje et al. (2001), professionals in agricultural sector such as researchers, farmers, educators and students believe that agricultural systems particularly; sustainable agriculture have the potential to address global issues like climate change, food insecurity, soil infertility and low yields. There exists a general consensus among researchers that sustainable agriculture is one among the best mechanism of agricultural practices that is good for mitigating climate change as well as sustaining the environment and humans. Ndah et al. (2015) reported that sustainable agriculture enhances environmental quality and the resource base on which agriculture depend, it provides for basic human food and fibre needs, and it's economically viable and enhances the quality of life for farmers and society as a whole in the long term. Moreover, Hayati et al. (2010) posited that sustainable agriculture is capable of maintaining its productivity and usefulness to society over the long run. He further asserted that, it must be environmentally sound, resource-conserving, economically viable, socially supportive and commercially competitive.

Sustainable agriculture is still in its infancy in Ghana and a better understanding of the system by the farmers is needed to attain the goals of sustainability. However, it should be noted that no agriculture is sustainable unless it is profitable and able to sustain the farming families in terms of healthy income and good quality of life. Thus, potential agricultural officers and farmers must be knowledgeable and convinced of the value of the sustainable agriculture to enable them in making an appropriate decision regarding its adoption. Knowledge is also known to be a component of individual behaviour hence, the need to examine agricultural students' perceptions of the concept.

The concept of sustainable agriculture as discussed by researchers centres on the actions of agriculture production agents especially farmers. The consequences of their actions either by practising; for instance, organic farming or inorganic (biotechnology, genetically modified, etc.) farming have impact on the current and future human generation and the quality of the environment simply put as climate change adversaries.

The behaviour of agricultural agents typically farmers and extension officers are influenced by their perceptions which influence their attitude towards every action they take in their farming activities (Adeola and Adetunbi 2015). Therefore, it is worth assessing at foremost the perception of students toward sustainable agriculture and climate change since they are potential of becoming agricultural extension officers and educators of farmers in Ghana and Sub-Saharan Africa at large. Better understanding of students' perception for sustainable agriculture, the barriers in environmental conservation and strategies to address them would be relevant in the formulation of policies regarding teaching, learning and practicing of agriculture. There are several arguments regarding the practice of genetically modified foods, the use of synthetic chemical fertilizers, pesticides, herbicides and other continual inputs, genetically modified 
organisms, heavy irrigation, intensive tillage, or concentrated monoculture production which make the agricultural sector economic viable, on the other side impact the environment negatively. In all these dilemma, most researchers agree that sustainable agriculture is the strategic means to address the challenge.

Despite the weighty influence agricultural students may have on farmers in the future (potential of becoming extension agents) with regards to their knowledge and perception on sustainable agriculture, very little research has been done globally to ascertain student's knowledge and their understanding of sustainable agriculture practices in order to revise educational (academic) curriculums and to aid in agricultural sustainability policy drafting and strategies. The perception and knowledge of agriculture students in Ghana on sustainable agriculture is necessary for future adaptation response by change agents (farmers) to sustainable farming due to the importance and contribution of farming to the Ghanaian economy. Currently in Ghana, very little information exists on students' self-assessed knowledge of the expected impact of sustainable agriculture as climate change mitigation strategy. An attempt to examine agriculture students' understanding and perception for sustainable agriculture, the barriers in environmental conservation and strategies to address them will be relevant in the formulation of policies regarding teaching, learning and practicing of sustainable agriculture in era of climate change in the country. It is therefore important and necessary to assess the perception of some Ghanaian agriculture students toward the concept of sustainable agriculture in respect of addressing climate change issues as well as to inform policy decisions and interventions in Ghana and SubSahara Africa at large.

The theory underlying this study is the Theory of Reasoned Action (TRA) by Ajzen (2005) which suggest that there exists a link between individuals' attitude, beliefs and their behaviour. According to the theory individuals' behaviour is dependent on their intentions and the intentions also depend on attitudes which implicitly or explicitly affect their performed actions. Behaviour of individuals are influenced by demographic variables such as age, sex, years of education, experience etc. This study therefore seeks to contribute to the knowledge pertaining to sustainable development by assessing students' perception for sustainable agriculture, its' adoption barriers and strategies to address them. Specifically, the objectives of this study are to; assess the perception of students toward sustainable agriculture, examine students' perception about the barriers in agricultural sustainability and their perceived strategies to address the barriers to sustainable agriculture practice adoption.

\section{Materials and methods}

\section{The study area}

The study was conducted in University of Ghana, Legon which lies between Longitude $0^{\circ} 11^{\prime} 7.80^{\prime \prime} \mathrm{E}$ and Latitude $5^{\circ} 39^{\prime} 1.79 " \mathrm{~N}$. The targeted population for this study was agricultural students in the School of Agriculture within the College of Basic and Applied Sciences of the University of Ghana. The University of Ghana was selected for the study since it is the premier and largest university with high reputation in agricultural sciences research and development. The School of Agriculture has over the years trained most of the agricultural service agents in Ghana therefore targeted for the study of student perceptions on adoption of sustainable agriculture as a climate change mitigation strategy in Ghana.

\section{Sampling technique and sample size}

A simple random technique (SRT) which gives all the individuals/people of the target population an equal chance of being selected was used to sample 120 agricultural students. The equal chance given to every member of the group eliminate sampling biases. The study was carried out in the 2017/2018 academic year. Primary data was obtained by the used of well-structured questionnaire which was adapted but modified 16 items designed by Veisi et al. (2008) administered to the students at the end of their lecture.

\section{Methods of analysis}

The study employed simple arithmetic mean technique expressed in Eq. (1) to identify students' perception for sustainable agriculture based on a sixteen-item formulated by Veisi et al. (2008). A mean technique for this study is represented in Eq. (1) as:

$$
\bar{x}=\frac{\sum x_{i}}{k}
$$

$\bar{x}=$ sampled mean, $x_{i}=$ the observed variables, and $k=$ total number of observations. $i=1,2,3, \ldots,=k$

Decision rule, given that a sustainable agriculture (item) statement has a mean $(\bar{x})$ such that $\bar{x}>3$, then the statement or item is deemed positive.

$\bar{x} \leq 3$, then the statement or item is deemed negative.

Also a perception score expressed in Eq. (2) was deemed statistically appropriate to compute an overall perception score for students' with regards to sustainable agriculture.

$$
P_{\text {score }(i)}=\frac{\sum\left(H_{1}+H_{2}+H_{3}+\cdots+H_{i}\right)}{k}
$$

for $Y_{i}=\frac{\sum i}{n}$, where $Y_{i}$ represents index computed for a particular statement under a main heading, $i=$ the figure 
assign to a particular scale, (such that $1=$ strongly disagree, $2=$ disagree, $3=$ uncertain, $4=$ agree, $5=$ strongly agree); $n=$ total observations, $k=$ the number of the main headings. $H_{i}=$ the index computed for a main heading (e.g. perception towards sustainable agriculture) $H_{i}=\frac{\sum\left(y_{1}+y_{2}+y_{3}+\cdots+y_{n}\right)}{q} ; q=$ the number of sub headings under the main headings. $\left(y_{1}+y_{2}+y_{3}+\cdots+y_{n}\right)=$ the summation of the indices computed for the individual statements.

In an attempt to test whether there exist significant difference between gender of a respondent and perception score, the T-Test statistic as illustrated in Eq. (3) was used.

Assuming Equal Population Variances/Standard Deviations, then a T-test statistics expressed as; confirm the model fit using confirmatory factor analysis. That is using the confirmatory approach to test formulated hypothesis based on the theoretical model on which the study is based upon.

Moreover, the study used the Kendall's coefficient of concordance $(\mathrm{W})$ to test the significant level of agreement among respondent with respect to the perceived barriers and measures to address the specified barriers in order to promote sustainable agriculture adoption as a tool to mitigate climate change. The Kendall's coefficient of concordance (W) is expressed in Eq. (4) as;

$$
W=\frac{12 * R}{m^{2}\left(k^{3}-k\right)}
$$

where; $m=$ the respondents, $k=t$ the number of barriers and ways to address them,

$R=$ the squared deviation.

$0 \leq W \leq 1 \quad$ where the test statistic $m(k-1) W \approx \chi^{2}(k-1)$ distribution

$$
t=\frac{\bar{x}_{A}-\bar{x}_{B}}{S E\left(\bar{x}_{A}-\bar{x}_{B}\right)}=\frac{\bar{x}_{A}-\bar{x}_{B}}{\sqrt{s_{p}^{2}\left(\frac{1}{n_{A}}+\frac{1}{n_{B}}\right)}} \sim t-\text { distribution } d f=n_{A}+n_{B}-2
$$

where,

$$
s_{p}^{2}=\frac{\left(n_{A}-1\right) s_{A}^{2}+\left(n_{Y}-1\right) s_{B}^{2}}{\left(n_{A}-1\right)+\left(n_{B}-1\right)} \text { or } s_{p}^{2}=\frac{s_{A}^{2}+s_{B}^{2}}{2} \text { when } n_{A}=n_{B}
$$

$s_{p}^{2}=$ Pooled-estimate of the common variance.

\section{Hypothesis}

$H_{o}: \mu_{M}=\mu_{F}$ or $\mu_{M}-\mu_{F}=0, f$ or no significant difference in gender and perception score.

$H_{a}: \mu_{M} \neq \mu_{F}$ or $\mu_{M}-\mu_{F} \neq 0$ (two - tailed), there exist a significant difference between gender and perception score.

Where $\mu_{M}=$ Mean number of Male and $\mu_{F}=$ Mean number of Female respondents.

To examine factors that influence students' perception regarding Adoption of Sustainable Agricultural Practices (ASAP) as a climate change mitigation strategy, structural equation modelling technique was used. Structural Equation Modelling (SEM) is a statistical process which can be used to test measurement, functional, predictive and causal hypothesis (Bagozzi and Yi 2012). The measurement model is therefore tested using the Smart PLS to

\section{Hypothesis}

$\mathrm{H}_{1}$ : There is no agreement among students' about the perceived barriers to sustainable agriculture.

$\mathrm{H}_{2}$ : There exists an agreement among students' about the perceived barriers to sustainable agriculture. 
$\mathrm{H}_{3}$ : There is no agreement among students' about the perceived strategies to sustainable agriculture. $\mathrm{H}_{4}$ : There exists an agreement among students' about the perceived strategies to sustainable agriculture.

The data collected was analysed by the use of statistical packages such as STATA version 14, Smart PLS 3 for the structural equation modelling and Excel 2013. A fivepoint Likert scale expressed as Strongly Disagree (1), Disagree (2), Neutral (3), Agree (4) and Strongly Agree (5) was employed in evaluating the agreement and disagreement among students on the listed items.

\section{Results}

\section{Demographic characteristics of the respondents}

Descriptive analysis of the 120 sampled agriculture students showed that $62.50 \%$ were males and $37.50 \%$ were females. The male dominance could possibly be due to strenuous and presumed idea that agriculture courses in Ghana are not attractive to female students. This goes to confirm the general assertion that agricultural programmes at the University level is both strenuous, difficult and not attractive to females, hence the male dominance. The ages of the respondents ranged between 20 to 29 years. Majority $(92.60 \%)$ of the respondents were within the age range of $21-25$ years and the average age as 22.76 years. On the religious demographics, it was found that Christians were $83.00 \%$, Muslims were $15.00 \%$ and other religious groups were $2.00 \%$.

\section{Students' cognitive competence with regards to sustainable agriculture}

To examine students' understanding of the concept of sustainable agriculture in the perspective of climate change mitigation, some statements that reflect students' awareness, knowledge and understanding of sustainable agriculture were used as presented in Table 1 . The results indicated that, $85.00 \%$ of the respondents claimed to have heard about sustainable agriculture whiles $14.20 \%$ of the respondents have not heard of sustainable agriculture. Also, findings on students who had taken a course on sustainable agriculture showed that $69.20 \%$ of the respondents representing "Yes", had once registered a course which taught them sustainable agriculture while the remaining $30.80 \%$ had never taken a course on sustainable agriculture. In an attempt to identify the proportion of students' who understand the concept of sustainable agriculture, it was revealed that, majority of the respondents representing $79.20 \%$ responded to "Yes" they understand whiles about $20.80 \%$ responded to "No" they did not understand the concept of sustainable agriculture. The descriptive statistics obtained in this study buttress and better reflect that of Veisi et al. (2008) and Adu-Tutu et al. (2013) who concluded from their studies that agricultural stakeholders are aware and have knowledge and understanding of sustainable agriculture and environmental conservation related concepts.

\section{Students' perception for sustainable agriculture}

The means technique was used to calculate for the significant variables. The decision yardstick used for the analysis was formulated based on mean ranges such that, items with mean values between 1 and 2.90 was deemed as "Disagreed" whiles items with mean values between 3.10 and 5.0 was deemed as "Agreed" based on the authors construct. With regards to students' perception for sustainable agriculture, sixteen items categorised into six components were considered. Results presented in Table 2 indicate that, students perceive sustainable agriculture as a practice that ensures environmental protection. The mean for the environmental protection component of sustainable agriculture was 3.93 representing quite a significant agreement by the students'. Analysis of mean outlined in Table 2 showed that about $78.04 \%$ of the students' agree that sustainable agriculture primarily ensures protection of the environment, such that an advantage of sustainable agricultural practices reduce the use of chemical fertilizers and farmers in sustainable agriculture live more in harmony with nature. Results obtained for this study similarly confirms findings reported by Adeola and Adetunbi (2015) and Sterve (2011). However, a difference in perception of about $35.22 \%$ of the sampled students' disagreed that sustainable agriculture renders much economic gains such as an increased net farm income to the farmer. On the aspect of management, majority of about $77.24 \%$ of the

Table 1 Students' awareness of sustainable agriculture as climate change strategy

\begin{tabular}{|c|c|c|c|c|c|}
\hline \multirow{2}{*}{$\begin{array}{l}\text { Awareness } \\
\text { Items }\end{array}$} & \multicolumn{2}{|l|}{ Yes } & \multicolumn{2}{|l|}{ No } & \multirow[t]{2}{*}{ Total } \\
\hline & Frequency & Percent & Frequency & Percent & \\
\hline Are you aware of sustainable agriculture? & 103 & $85.8 \%$ & 17 & $14.2 \%$ & 120 \\
\hline Have you taken course on sustainable agriculture before? & 83 & $69.2 \%$ & 37 & $30.8 \%$ & 120 \\
\hline Do you understand the concept of sustainable agriculture? & 95 & $79.2 \%$ & 25 & $20.8 \%$ & 120 \\
\hline
\end{tabular}

Source: Field survey (2018) 
Table 2 Students' perception on sustainable agriculture related variables

\begin{tabular}{|c|c|c|c|}
\hline Variable & Description & Mean & Std. Dev \\
\hline \multirow[t]{3}{*}{ Environmental protection } & $\begin{array}{l}\text { Environmental balance (climate change mitigation) is one basis for sustainable agricultural } \\
\text { practices }\end{array}$ & 3.58 & 1.55 \\
\hline & An advantage of sustainable agricultural practices is reduction in the use of chemical fertilizers & 4.04 & 0.89 \\
\hline & Farmers in sustainable agriculture live more in harmony with nature & 4.18 & 0.75 \\
\hline \multirow[t]{3}{*}{ Economic } & Economic gains when employing sustainable agricultural practices are not convincing & 1.70 & 0.59 \\
\hline & Net farm income may decrease when a producer implements sustainable agricultural practices & 1.75 & 0.60 \\
\hline & Sustainable agricultural systems can improve income on a farm & 3.63 & 1.30 \\
\hline \multirow[t]{3}{*}{ Management } & Sustainable agricultural practices would work well on farm & 3.58 & 1.16 \\
\hline & $\begin{array}{l}\text { Sustainable agricultural practices may require additional management beyond conventional } \\
\text { practices }\end{array}$ & 3.62 & 1.11 \\
\hline & $\begin{array}{l}\text { The adoption of sustainable agricultural practices is slow because farmers lack the knowledge to } \\
\text { implement them }\end{array}$ & 4.23 & 0.62 \\
\hline \multirow[t]{3}{*}{ Sustainable agricultural practices } & $\begin{array}{l}\text { Recommended pest control methods for sustainable agricultural systems have potential for more } \\
\text { pests in the long term }\end{array}$ & 2.37 & 0.74 \\
\hline & $\begin{array}{l}\text { Sustainable agricultural practices help protect the environment, natural resources and mitigate } \\
\text { climate }\end{array}$ & 4.33 & 0.78 \\
\hline & There may be insufficient labour for the workload required in sustainable agricultural system & 2.33 & 0.92 \\
\hline \multirow[t]{2}{*}{ Likelihood } & $\begin{array}{l}\text { Sustainable agricultural systems should produce an adequate food supply to feed the world } \\
\text { population }\end{array}$ & 3.91 & 1.02 \\
\hline & $\begin{array}{l}\text { Recommended practices in sustainable agriculture have been embraced by mainstream agricul- } \\
\text { ture }\end{array}$ & 3.41 & 0.90 \\
\hline \multirow[t]{2}{*}{ System of sustainable agriculture } & $\begin{array}{l}\text { Adoption of sustainable agricultural practices will be easier for farmers who have cropped and } \\
\text { livestock enterprises }\end{array}$ & 2.23 & 1.14 \\
\hline & $\begin{array}{l}\text { Make the most efficient use of non-renewable resources and on-farm resources and integrate, } \\
\text { where appropriate, natural biological cycles and controls }\end{array}$ & 3.34 & 1.02 \\
\hline
\end{tabular}

Source: Field survey (2018)

students agreed that an adoption of sustainable agricultural practices is slow because farmers lack the knowledge to implement them and its practices may require additional management beyond conventional practices. Besides, majority of the students' representing $39.44 \%$ showed disagreement that sustainable agricultural system may require insufficient labour on the farm, however, about $60.56 \%$ of the sampled students' strongly agreed that sustainable agricultural practices help protect the environment and our natural resources. The findings of this study is in line with authors like Williams (2000) and Veisi et al. (2008) who found that sustainable agricultural practices help protect the environment and our natural resources. Furthermore, about $85 \%$ of the sampled students' agreed that sustainable agricultural systems are capable to produce an adequate food supply to feed the world population but disagreed that the adoption of sustainable agricultural practices will be easier for farmers who have crop and livestock enterprises. Notwithstanding the agreement and disagreement to some factors or statement regarding students' perception for sustainable agriculture adoption as climate change mitigation strategy, an analysis of difference of means (T-test) indicated no significant $(\mathrm{t}-\mathrm{cal}<\mathrm{t}$-ratio, $\mathrm{df}=118 ; \mathrm{p}=0.425>0.05)$ difference between gender of a respondent and perception score; as presented in Table 3.

Table 3 Gender difference and perception score for sustainable agriculture

\begin{tabular}{llllllll}
\hline Variable & Gender & $N$ & Mean & Std & Df & t-cal & Sig. level \\
\hline Perception score & Male & 75 & 33.053 & 7.461 & 118 & -0.801 & 0.425 \\
& Female & 45 & 34.088 & 5.684 & & $p>0.05$ \\
\hline
\end{tabular}

Source: Field survey (2018) 


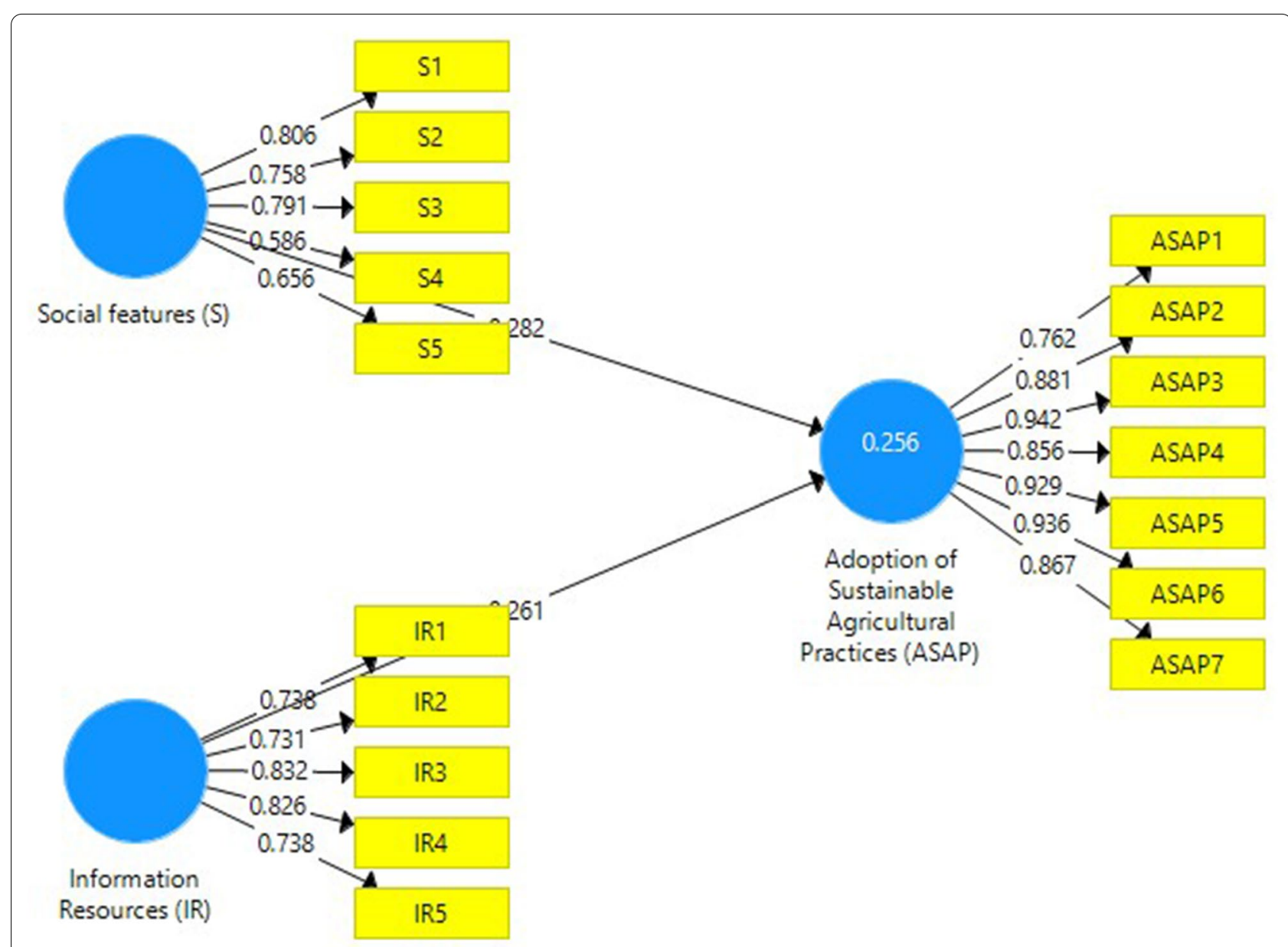

Fig. 2 Graphical linkage between constructs on sustainable agriculture adoption

\section{Structural equation modelling of student perceived} factors that influence adoption of sustainable agriculture practices

Perceived factors of students' regarding sustainable agriculture showed statistically significant and positive relationship between independent constructs and the dependent construct "Adoption of Sustainable Agricultural Practices" (ASAP) as a climate change mitigation strategy. Graphical illustration of the relationship between dependent and independent variables is shown in Fig. 2 Per the results presented in Table 6 of the SmartPLS structural equation modelling, it was revealed that various items with their outer loadings under each indicator was highly significant.

Evaluation of an internal consistency for this study is judged by the construct reliability. The test for internal consistency for the model indicated that all indicators are internally consistent as presented in Table 4. However,

Table 4 Construct reliability and validity diagnostics

\begin{tabular}{llll}
\hline Construct & Cronbach's Alpha & rho_A & $\begin{array}{c}\text { Average } \\
\text { Variance } \\
\text { Extracted (AVE) }\end{array}$ \\
\hline $\begin{array}{l}\text { Adoption of Sustainable Agricultural } \\
\quad \text { Practices (ASAP) }\end{array}$ & 0.952 & 0.957 & 0.961 \\
$\begin{array}{l}\text { Information Resources (IR) } \\
\text { Social features (S) }\end{array}$ & 0.833 & 0.781 & 0.847 \\
\hline
\end{tabular}

Source: Field survey (2018) 
Table 5 Outer loadings of sustainable agriculture adoption factors

\begin{tabular}{|c|c|c|c|}
\hline Factor/indicator & $\begin{array}{l}\text { Adoption of Sustainable } \\
\text { Agricultural Practices } \\
\text { (ASAP) }\end{array}$ & $\begin{array}{l}\text { Information } \\
\text { Resources (IR) }\end{array}$ & Social features (S) \\
\hline ASAP1_-Practice farm waste collection & 0.762 & & \\
\hline ASAP2 - Organise educational classes on sustainable agriculture and climate change & 0.881 & & \\
\hline ASAP3 — Promote protection of arable lands & 0.942 & & \\
\hline ASAP4_-Protection of forest from illegal mining (galamsey) activities & 0.856 & & \\
\hline ASAP5—Implementation of environmental protection projects & 0.929 & & \\
\hline ASAP6-Use non-chemical methods to combat crop-associated pests and diseases & 0.936 & & \\
\hline ASAP7-Use green manure and organic fertilizers, etc. in crop farming & 0.867 & & \\
\hline IR1-Surfing the net on environmental protection & & 0.738 & \\
\hline IR2-Watch educational movies on environmental protection & & 0.731 & \\
\hline IR3-Communication with experts on environmental protection and climate change & & 0.832 & \\
\hline IR4-Awareness on aftermaths of destroying the environment on climate change & & 0.826 & \\
\hline IR5-Use newspaper, magazine, radio and television on environmental protection & & 0.738 & \\
\hline S1 - Interest of farmer in group activities related to environmental protection & & & 0.806 \\
\hline S2-Communication with other farmers & & & 0.758 \\
\hline S3-Communication with agricultural service centers & & & 0.791 \\
\hline S4-Refer to farmer for farming difficulties & & & 0.586 \\
\hline S5-Communication of farmer with Environmental Protection Agency (EPA) & & & 0.656 \\
\hline
\end{tabular}

Source: Field survey (2018)

in some instances based on model statistics, some items of indicators of information resource and social features were dropped because it poorly loads on the respective constructs. The results of the test of internal consistency, reliability and validity for the model is shown in Table 4 .

The results presented in Table 5 and Fig. 2 showed an $R^{2}$ of 0.256 with highly significant $p$ value of 0.001 indicating that the overall model is significant. According to Tjur (2009) analysis of coefficients of determination $\left(R^{2}\right)$ in regression models, it is certainly not because a model with a low value of $R^{2}$ is necessarily a bad model. We can have an appropriate model with a low $R^{2}$ if the design of the experiment is such that the values of the explanatory variables are kept in a narrow domain. This is true for this study because several explanatory variables were kept within the three main composite factors such as; Information Resources (IR), Social features (S) and Adoption of Sustainable Agricultural Practices (ASAP). An estimation of a parameter function and its related factor loadings as computed in this present study on sustainable agriculture adoption by the use of Smart PLS algorithm are presented in Table 6 . The overall reliability and validity of the model considered for this study per the Cronbach's Alpha of the three main variables; Information Resources $(I R=0.833)$, Social features $(S=0.780)$ and Adoption of Sustainable Agricultural Practices (ASAP $=0.952$ ) were statistically justified since the Cronbach's Alpha are greater than 0.70 (Hair et al., 2012).
Social features including promotion of "interest of farmer in group activities related to environmental protection", "communication with other farmers", "communication with agricultural service centers", and communication of farmer with Environmental Protection Agency (EPA) or officers" were identified as major social intervention or strategies agriculture agents and stakeholder at large could employ in influencing farmers adoption of sustainable agricultural practices in Ghana. Moreover, Information Resource strategies in the forms of encouraging farmers and students to watch educational movies on environmental protection, communication with experts on environmental protection, awareness on aftermaths of destroying the environment. More importantly, the use of newspapers, magazines, radio and television on the need to conserve environmental resources is deemed significant in an attempt to influence farmer's and agriculture students' adoption of sustainable agricultural practices in Ghana. Therefore, proper implementation of social features and information resources would influence adoption of sustainable agricultural practices if attempts are made to organise educational classes on sustainable agriculture, promote protection of arable lands, implementation of environmental protection projects, use non-chemical methods to combat crop-associated pests and diseases, use green manure and organic fertilizers in crop farming. 
Table 6 Outer loadings of variables on perceived sustainable agriculture adoption as a climate change mitigation strategy

\begin{tabular}{|c|c|c|c|c|c|}
\hline Construct & Coefficient & Mean & $\begin{array}{l}\text { Standard } \\
\text { Deviation }\end{array}$ & T Statistics & PValues \\
\hline Adoption of Sustainable Agriculture Practices (ASAP1) & 0.762 & 0.751 & 0.077 & 9.954 & $0.000^{* * *}$ \\
\hline Adoption of Sustainable Agriculture Practices (ASAP2) & 0.881 & 0.878 & 0.048 & 18.408 & $0.000^{* * *}$ \\
\hline Adoption of Sustainable Agriculture Practices (ASAP3) & 0.942 & 0.938 & 0.022 & 43.288 & $0.000^{* * *}$ \\
\hline Adoption of Sustainable Agriculture Practices (ASAP4) & 0.856 & 0.852 & 0.064 & 13.310 & $0.000^{* * *}$ \\
\hline Adoption of Sustainable Agriculture Practices (ASAP5) & 0.929 & 0.923 & 0.028 & 32.745 & $0.000^{* * *}$ \\
\hline Adoption of Sustainable Agriculture Practices (ASAP6) & 0.936 & 0.931 & 0.024 & 38.441 & $0.000^{* * *}$ \\
\hline Adoption of Sustainable Agriculture Practices (ASAP7) & 0.867 & 0.854 & 0.055 & 15.704 & $0.000^{* * *}$ \\
\hline Information Resource (IR1) & 0.738 & 0.695 & 0.123 & 6.003 & $0.000^{* * *}$ \\
\hline Information Resource (IR2) & 0.731 & 0.660 & 0.184 & 3.973 & $0.000^{* * *}$ \\
\hline Information Resource (IR3) & 0.832 & 0.780 & 0.132 & 6.282 & $0.000^{* * *}$ \\
\hline Information Resource (IR4) & 0.826 & 0.814 & 0.087 & 9.493 & $0.000^{* * *}$ \\
\hline Information Resource (IR5) & 0.738 & 0.735 & 0.088 & 8.396 & $0.000^{* * *}$ \\
\hline Social features (S1) & 0.806 & 0.797 & 0.078 & 10.387 & $0.000^{* * *}$ \\
\hline Social features (S2) & 0.758 & 0.748 & 0.097 & 7.853 & $0.000^{* * *}$ \\
\hline Social features (S3) & 0.791 & 0.755 & 0.118 & 6.691 & $0.000^{* * *}$ \\
\hline Social features (S4) & 0.586 & 0.533 & 0.181 & 3.241 & $0.001^{* * *}$ \\
\hline Social features (S5) & 0.656 & 0.600 & 0.154 & 4.267 & $0.000^{* * *}$ \\
\hline
\end{tabular}

Source: Field survey (2018)

The measure of the relative relevance of each indicator in the measurement of the construct is revealed by the value of the indicator loadings and their statistical significance. The indicator loadings are calculated by the basic Smart-PLS algorithm. A summary statistics of the indicator loadings and their statistical significance are shown in Table 6. A good standardised loading estimate should be equal to or greater than 0.70 (Hair et al. 2012). Results indicated all items under the various constructs significant at 1 percent level. There exist positive and a greater magnitude of coefficient for most of the items of respective constructs that affect student perception with respect to social features and information resources. The items with greater coefficient above 0.70 could be given more attention in decision making on dilemmas' on optimizing agriculture production at the expense of environmental protection and otherwise. More importantly, the items with coefficients of 0.70 and greater with significant $\mathrm{p}$ values could simply be employed to influence agriculture stake holders like students who would become extension officers subsequently to influence farmers' towards the adoption of sustainable agriculture and environmental conservation practices that could mitigate climate change.

\section{Students' perception about the barriers in adopting sustainable agriculture}

In an attempt to assess the students' perceived barriers in adoption of sustainable agriculture as a climate change
Table 7 Ranking of barriers in adopting sustainable agriculture as climate change strategy

\begin{tabular}{lll}
\hline Barriers & Mean Score & Rank \\
\hline Economic cost barriers & 1.50 & $1^{\text {st }}$ \\
Lack of knowledge & 2.23 & $2^{\text {nd }}$ \\
Land tenure & 3.12 & $3^{\text {rd }}$ \\
Education and Information & 3.98 & $4^{\text {th }}$ \\
Compatibility with new technology & 5.53 & $5^{\text {th }}$ \\
Farm management skills & 5.60 & $6^{\text {th }}$ \\
Awareness & 6.03 & $7^{\text {th }}$ \\
$N=120$ & Degree of freedom $=6$ \\
Kendall's $(W)=0.69$ & Asymp. Sig. at & \\
Chi-square $=494.41$ & P-Value $=0.001$ & \\
\hline
\end{tabular}

Source: Field survey (2018)

mitigation strategy by agricultural agents, the Kendall's coefficient of concordance (W) was used to evaluate the level of agreement among the identified and ranked barriers by the students. Results presented in Table 7 show the mean scores where the least scores indicate the major barriers otherwise deemed least barrier. Sampled students' perceived economic cost (mean score $=1.50$ ) as the most pressing barrier to sustainable agriculture followed by farmers' lack of knowledge (mean score $=2.23$ ) as second then constraints in land tenure systems (mean score $=3.12$ ) as third ranked barrier. Lack of education and information (mean score $=3.98$ ) was also considered 
as the fourth barrier whiles compatibility to new technology (mean score $=5.53$ ) and farm management skills (mean score $=5.60$ ) were ranked fifth and sixth barriers respectively. The least considered barrier to adoption of sustainable agriculture was identified as farmer awareness of sustainable agriculture practices (mean score $=6.03$ ). The findings of this study confirm that of the empirical evidence reported by Williams (2000), Veisi et al. (2008), Rodriguez et al. (2009), Khwidzhili \& Worth (2020) regarding the perspectives of change agents including extension officers, agriculture students and farmers in particular often struggle to obtain accurate information about the benefits of sustainable agriculture practices. It has been demonstrated that government support programs often fail to encourage adoption as a result of inadequate funding, inappropriate design and ineffective targeting of farmers widespread adoption of sustainable agriculture practices.

The overall estimated Kendall's coefficient of concordance (W) is 0.69 which is asymptotically significant at $5 \%$ and was consistent with the Friedman's correlation $(r=0.68)$ test statistics. This means that there is 69 percent agreement among the students' rankings of the perceived barriers in adopting sustainable agriculture. Therefore, the null hypothesis which states that there is no agreement among the rankings of barriers is rejected. Since the $P$-Value $=1.35 E-103 \sim 0.001$, it is indicated that there is an agreement among the students ranking of perceived barriers to sustainable agriculture.

\section{Students' perceived strategies to address the barriers to sustainable agriculture}

According to the results outlined in Table 8, it was suggested by the sampled agriculture students that amongst the major strategic ways to address barriers to adopting sustainable agriculture as a climate change mitigation tool were farmer-to-farmer education (mean score $=1.07$ ), financial incentives to farmers (mean score $=2.29$ ) who patronise sustainable agriculture, designing training and

Table 8 Ranking strategies to address barriers to sustainable agriculture adoption

\begin{tabular}{lll}
\hline Strategy & Mean Score & Ranked \\
\hline Farmer to-farmer-education & 1.07 & $1^{\text {st }}$ \\
Financial incentives & 2.29 & $2^{\text {nd }}$ \\
Training and partnership & 3.03 & $3^{\text {rd }}$ \\
Participatory learning & 3.61 & $4^{\text {th }}$ \\
$\mathrm{N}=120$ & Degree of freedom $=3$ & \\
Kendall's $(\mathrm{W})=0.72$ & Asymp. Sig. at & \\
Chi-square $=259.97$ & P-Value $=0.001$ & \\
\hline
\end{tabular}

Source: Field survey (2018) partnership (mean score $=3.03$ ) for farmers and participatory learning (mean score $=3.61$ ) as presented in Table 8 with the mean scores and ranks ordered. The computed Kendall's coefficient of concordance (W) is 0.72 which is asymptotically significant at $5 \%$ and was consistent with the Friedman's correlation $(r=0.71)$ test statistics. This means that there is $70 \%$ agreement among the students' rankings of the perceived strategies to address barriers in adopting sustainable agriculture. Therefore, the null hypothesis which states that there is no agreement among the rankings of barriers is rejected. Since the $P$-Value $=4.56 E-56 \sim 0.001$, it is indicated that there is an agreement among the students ranking of perceived strategies to address the identified barriers to sustainable agriculture adoption as climate change strategy in Ghana.

\section{Conclusions}

The study concludes that agriculture students in the School of Agriculture within the College of Basic and Applied Sciences, University of Ghana have a favourable disposition toward sustainable agriculture as a tool to mitigating adverse effect of climate change. This is evident in their agreement with the most of the positive statements and disagreement with the negative statements regarding sustainable agriculture. Generally, majority of the sampled agriculture students expressed their understanding of the concept of sustainable agriculture. Environmental balance was revealed by majority of the students to be the basis for sustainable agricultural practices. Most of the students were of the view that farmers in sustainable agriculture live more in harmony with nature, but the adoption of sustainable agricultural practices is slow because farmers lack the knowledge to implement them though it would work well on farms. Besides, it was confirmed that, sustainable agricultural practices would help protect the environment and our natural resources and is capable of providing food security to Ghana and Sub-Saharan Africa at large. There was no significant difference between gender and perception score of the respondents toward sustainable agriculture.

The use of radio, newspapers, magazines, and television on the need to conserve environmental resources is deemed significant in efforts to influence agriculture students' who potentially have influence on farmers' as emerging extension officers on the adoption of sustainable agricultural practices in Ghana. It is therefore suggested that Environmental Protection Agency (EPA), Ministry of Agriculture as well as the Ministry of Environment Science and Technology pay attention to the key issues on social features and information resources raised in this study in formulation of agriculture sector production and environmental conservation policies. 
Major barriers to sustainable agriculture was mostly perceived by students' as economic costs, lack of knowledge, land tenure constraints, lack of education and information, etc. the study recommends farmer-tofarmer education on the need to protect the environment from inorganic farming activities that deplete/degrade soil. Also, government and private organisations should allocate intervention subsidies to address economic costs incurred by farmers who adopt sustainable agricultural practices. Developing training and partnership programs and implementing farmer participatory learning approaches would to some extent address the barriers to sustainable agricultural practices.

\section{Abbreviations}

GSS: : Ghana Statistical Service; GDP: Gross domestic product; UN: United Nations; MoFA: Ministry of Food and Agriculture; Fig: Figure; Asymp. Sig.: Asymptotically significant; SAP: Sustainable Agriculture Practice; FAO: Food and Agriculture Organisation.

\section{Acknowledgements}

We thank students who freely participated in the research, we are grateful to the Extension Officers of the Ministry of Food and Agriculture (MoFA) and some lecturers of the University of Ghana, Legon, School of Agriculture for their useful suggestions on the content of this study. We acknowledge the comments from anonymous reviewers.

\section{Authors' contributions}

AJ conceived and designed the work with TKT, and AJ validated the method section. All authors AJ; TKT and AM participated in the analysis, validation and writing of the paper. All authors read and approved the final manuscript.

\section{Funding}

This study was not funded by any grant.

\section{Availability of data and materials}

Part of the data that supports the findings are included in the manuscript. The raw data of the study are available upon request from the corresponding author.

The data used to support the findings of this study are available on these google drive links: https://drive.google.com/open?id=1BXb693Ey5ONpBt b7IEPznRTaTxQsosLL and https://drive.google.com/open?id=1c3vaaM7uB wUx28A9YivT0TmSJEgb8xXJ and https://drive.google.com/file/d/12Die6f1zQ WW3NXANf5U-1YIn9fdb5y7G/view? usp=sharing

\section{Declarations}

\section{Ethics approval and consent to participate}

Informed consent was obtained from all student participants involved in the study. All participants freely agreed to participate in the study without reservation.

\section{Consent for publication}

Consent to publish individual data in any form was obtained from the participants interviewed.

\section{Competing interests}

The authors declare no competing interests.

\section{Author details}

${ }^{1}$ Department of Economics, Friedrich-Schiller-Universität Jena, Jena, Germany. ${ }^{2}$ Department of Agricultural Economics and Agribusiness, University of Ghana, P. O. Box LG 68, Legon, Accra, Ghana.
Received: 14 January 2021 Accepted: 1 April 2021

Published online: 10 April 2021

\section{References}

Abraham M, Pingali P (2020) Transforming smallholder agriculture to achieve the SDGs. In: Gomez y Paloma S, Riesgo L, Louhichi K (eds) The role of smallholder farms in food and nutrition security. Springer, Cham. https:// doi.org/10.1007/978-3-030-42148-9_9

Adeola RG, Adetunbi SI (2015) Farmers' perception of sustainable agriculture in South-Western Nigeria: implications for rural economy. Int J Appl Agric Apicult Res 11(1-2):86-92. https://www.ajol.info/index.php/ijaaar/article/ view/141579

Adu-Tutu F, Yeboah AS, Darkwa B (2013) Environmental concern: a survey of students attitude in Sunyani Polytechnic. Int J Innov Res Manage 2(3):1-10

Agbaje KAA, Martin RA, Williams DL (2001) Impact of sustainable agriculture on secondary school agricultural education teachers and programs in the north central region. J Agric Educ 42(2):38-45. https://doi.org/10.5032/ jae.2001.02038

Agbenyo W, Jiang YS, Antony S (2019) Cointegration analysis of agricultural growth and financial inclusion in Ghana. Theor Econ Lett 9:895-911. https://doi.org/10.4236/tel.2019.94058

Ajzen I (2005) Attitudes, personality, and behavior. McGraw-Hill Education, New York

Alexandratos N, Bruinsma J (2012) World agriculture towards 2030/2050: the 2012 revision, Vol. 12, No. 3. FAO, Rome: ESA Working paper. http://www. fao.org/fileadmin/templates/esa/Global_persepctives/world_ag_2030_ 50_2012_rev.pdf

Altieri MA (2002) Agroecology: the science of natural resource management for poor farmers in marginal environments. Agr Ecosyst Environ 93(1-3):1-24. https://doi.org/10.1016/S0167-8809(02)00085-3

Bagozzi PR, Yi Y (2012) Specification, evaluation, and interpretation of structural equation models. Acad Market Sci 40:8-34. https://doi.org/10.1007/ s11747-011-0278-x

FAO (2016) Food and Agriculture: key to achieving the 2030 agenda for sustainable development. The Food and Agriculture Organisation of the United Nations, 2016. http://www.fao.org/documents/card/en/c/d569c 955-8237-42bf-813e-5adf0c4241b9/

GSS (2016) Revised 2015 Annual Gross Domestic Product (1st ed.). Accra: Ghana Statistical Service. http://www.statsghana.gov.gh/

Hair JF, Sarstedt M, Ringle CM, Mena JA (2012) An assessment of the use of partial least squares structural equation modeling in marketing research. J Acad Mark Sci 40(3):414-433. https://doi.org/10.1007/ s11747-011-0261-6

Hayati D, Ranjbar Z, Karami E (2010) Measuring agricultural sustainability. In: Lichtfouse $\mathrm{E}$ (eds) Biodiversity, biofuels, agroforestry and conservation agriculture. Sustainable Agriculture Reviews, vol 5, pp 73-100. Springer, Dordrecht. https://doi.org/https://doi.org/10.1007/978-90-481-9513-8_2

Hoekstra AY, Chapagain AK (2006) Water footprints of nations: water use by people as a function of their consumption pattern. In Integrated assessment of water resources and global change. Springer, Dordrecht, pp. 35-48. https://link.springer.com/article/10.1007\%2Fs11269-006-9039-x

Khwidzhili RH, Worth S (2020) Promotion of sustainable agriculture by mpumalanga agricultural extension services: perspective of public extension pratictioners. S Afr J Agric Extens 48(1):1-16. http://doi.org/https://doi. org/10.17159/2413-3221/2020/v48n1a522

Kwarase PK (2017) Analysing trends in agricultural output in Ghana 1995 2015: Underlying causes and options for sustainable growth (Doctoral dissertation). https://core.ac.uk/reader/197725801

MoFA. (2016). Agriculture in Ghana: Facts and Figures (2015). Accra: Ministry of Food and Agriculture; Statistics, Research and Information Directorate (SRID). http://www.agrofood-westafrica.com/fileadmin/user_upload/ messen/agrofood-Westafrica/Brochure/AGRICULTURE-IN-GHANA-Factsand-Figures-2015.pdf

Ndah HT, Schuler J, Uthes S, Zander P, Triomphe B, Mkomwa S, Corbeels M (2015) Adoption potential for conservation agriculture in Africa: a newly developed assessment approach (QAToCA) applied in Kenya and Tanzania. Land Degrad Dev 26(2):133-141. https://doi.org/10.1002/ldr.2191 
Paramati SR, Alam MS, Chen CF (2017) The effects of tourism on economic growth and $\mathrm{CO} 2$ emissions: a comparison between developed and developing economies. J Travel Res 56(6):712-724. https://doi.org/10. $1177 / 0047287516667848$

Rodriguez JM, Molnar JJ, Fazio RA, Sydnor E, Lowe MJ (2009) Barriers to adoption of sustainable agriculture practices: Change agent perspectives. Renew Agric Food Syst 24(1):60-71. https://doi.org/10.1017/S174217050 8002421

Schaffnit-Chatterjee C, Lanzeni ML, AG, DB, Hoffmann R (2014) Agricultural value chains in Sub-Saharan Africa. From a development challenge to a business opportunity. Deutsche Bank Research, Frankfurt. pp. 1-28

Sterve H (2011) Factors restricting adoption of sustainable agricultural practices in a smallholder agro-ecosystem: a case study of Potshini community, upper Thukela region, South Africa. https://www.diva-portal.org/ smash/get/diva2:439921/FULLTEXT01.pdf

Tjur T (2009) Coefficients of determination in logistic regression models - a new proposal: the coefficient of discrimination. Am Stat 63(4):366-372. https://doi.org/10.1198/tast.2009.08210
Tuomisto HL, Hodge ID, Riordan P, Macdonald DW (2012) Does organic farming reduce environmental impacts? - a meta-analysis of European research. J Environ Manage 112:309-320. https://doi.org/10.1016/j.jenvm an.2012.08.018

Veisi H, Hematyar H, Azarkerda H (2008) Exploring the relationship between students knowledge and perceptions towards sustainable agriculture. J Environ Sci 5(2):39-50. https://www.sid.ir/en/journal/ViewPaper.aspx? $\mathrm{id}=125858$

Williams DL (2000) Student's knowledge of and expected impact from sustainable agriculture. J Agric Educ 41(2):19-24. http://citeseerx.ist.psu.edu/ viewdoc/download?doi=10.1.1.557.5049\&rep=rep1\&type $=$ pdf

\section{Publisher's Note}

Springer Nature remains neutral with regard to jurisdictional claims in published maps and institutional affiliations.

\section{Submit your manuscript to a SpringerOpen ${ }^{\circ}$ journal and benefit from:}

- Convenient online submission

- Rigorous peer review

- Open access: articles freely available online

- High visibility within the field

- Retaining the copyright to your article

Submit your next manuscript at $\gg$ springeropen.com 